'MILITANZ' AND MORALISED VIOLENCE:

\title{
HAMBURG'S ROTE FLORA AND THE 2017 G20 RIOT
}

\author{
Ali Jones \\ Das ist Militanz. Gewalt ist das, was die anderen machen und wir sind militant. Also!’1
}

\begin{abstract}
'Militanz' as moralised political violence has been applied by the radical Left since the 1960s, but has scarcely been defined in academic literature. In the particular West German context, 'Militanz' has been restricted to attacks against objects rather than persons, in contradistinction to the terrorist attacks of the 1970s. The Autonomist movement has further theorised this concept through the caveat of the "three Antis' (Racism, Sexism, Capitalism), against which they consider their violence to be morally justified. This article offers a genealogy and definition of this 1990s Autonomist 'Militanz' by relying on extensive archival research and oral histories collected within the Hamburg Rote Flora Autonomist milieu. It then interrogates both this concept and the group's claims to moral authority by working within the Autonomists' own conceptual definition to apply 'Militanz' categorically to a riot during the 2017 G20 summit. The article untangles the various ideological factions who took part in this riot, and challenges media discourses that the Rote Flora Autonomists were responsible. However, it also concludes that 'Militanz' as a purely 'Anti' stance cannot legitimate moralised violence without offering any affirmative definition of appropriate political action, lest all violence become acceptable 'Militanz'.
\end{abstract}

'Militanz' wird seit den 1960er Jahren von linksradikalen Bewegungen verwendet, aber ist kaum in der wissenschaftlichen Literatur definiert. Insbesondere im westdeutschen Kontext wurde als 'Militanz' betrachtet was gegen Objekte gerichtet war; im Gegensatz zu den Terroranschlägen der 1970er Jahre, welche sich gegen Personen richteten. Die autonome Bewegung hat dieses Konzept durch den Vorbehalt der 'drei Antis' (Rassismus, Sexismus, Kapitalismus) weiter ausgearbeitet, gegen den sie ihre Gewalt als moralisch gerechtfertigt ansieht. Dieser Artikel bietet eine Genealogie und Definition dieser autonomen Militanz der 1990er Jahre, indem sie sich auf umfangreiche Archivrecherchen und Interviews stützt, die im Umfeld des autonomen Rote Flora Kulturzentrums gesammelt wurden. Indem dieser Artikel diese Konzepte von Militanz in den Definitionen der autonomen Bewegung anwendet, werden diese und die Ansprüche der autonomen Bewegung auf moralische Autorität im Kontext der 2017 G20 Krawalle erforscht. Dieser Artikel entwirrt die verschiedenen ideologischen Lager, die an den Krawallen teilgenommen haben und erkundet, warum gerade die Flora-Gruppe in den Medien als hauptverantwortlich für die Krawalle dargestellt worden war. Aber er kommt auch zum Schluss, dass 'Militanz' als als eine reine 'Anti-Haltung' moralisierte Gewalt nicht legitimieren kann, ohne eine angemessene politische Handlungsweise zu affirmieren. Sonst könnte alle Gewalt als 'Militanz' akzeptabel werden.

Militancy as a term is often associated with a struggle for social justice, and the radical German Left have framed their struggles as righteous counterviolence ('Gegengewalt') since at least $1967{ }^{2}$ However, while militancy is often stylised as self-defence against state structural violence, the term 'Militanz' has taken on a further meaning since the effective end of the Red Army Fraction (RAF) during 
the 1977 German Autumn. Conceptualised after the failure of the RAF's revolutionary dreams of an erstwhile Marxism, Autonomist 'Militanz' after 1977 explicitly refused the use of violence against people. Practitioners justified their 'counter-violence' as self-defence against structural violence, but now specifically re-formulated as the self-embodiment of the three 'Antis': the resistance to Racism, Capitalism, and Sexism in everyday life. $^{3}$ While similar claims to moral legitimacy have echoed throughout the history of the radical German Left, the Hamburg Rote Flora Autonomist milieu, who have squatted the Rote Flora Counter Culture Centre since 1989, have adopted this particular threefold justification as the unique grounding of their own political practice. However, the July 2017 G20 protests, which some Flora members helped co-organise, brought this problematic definition into stark relief, and demonstrated the inherent contradictions of a small group claiming moral authority. This article will offer a definition of this particular form of political violence, within the post-1977 historical context. It will also interrogate the moralizing claim of the Hamburg Autonomists, and debate whether such a justification is ever possible by pointing to the conceptual conflations and contradictions that became apparent during the 2017 anti-G20 riot.

\section{'MILITANZ': CONCEPT AND DEFINITION IN ROTE FLORA 'AUTONOMIE'}

The Rote Flora Culture Centre was founded in 1989, in response to the urban restructuring program initiated by a public-private partnership between the State Senate and the Stadterneuerungsgesellschaft (STEG). ${ }^{4}$ The old 'Flora' theatre, built in 1835, was located at the heart of the $0,47 \mathrm{~km}^{2}$ Schanzenviertel (Schanze), and was targeted by a gentrification campaign that would ultimately relocate low-income residents in order to raise land values and create an attractive new locale for 'creative' industries and entertainment complexes. ${ }^{5}$ As part of this programme, the theatre would be replaced by a new 'crystal palace' for the performance of the Phantom of the Opera Musical. ${ }^{6}$ When local residents learned of this planned restructuring, they feared rising rents, increased traffic and displacement,

and so engaged in two years of peaceful protests, petitions and marches. ${ }^{7}$ After numerous protests, as well as petitions signed by 2000 of the neighbourhood's roughly 2500 residents, 250 citizens were invited to 
voice their concerns on 17 March $1988 .{ }^{8}$ In this same spirit of negotiation, on 20 April the newly formed 'Flora Gruppe e.V.' were invited to visit the Senate to present their proposed alternative 'Nutzungskonzept' for the building as a neighbourhood culture centre rather than entertainment complex. ${ }^{9}$ Despite these symbolic concessions, demolition of the old building nevertheless began the next day, 21 April, under heavy police protection, destroying all but the former entrance hall and façade. ${ }^{10}$ This created disillusionment amidst the citizens initiative with the seemingly futile negotiations, while the more radical Rote Flora Autonomists became convinced that militant violence was the only way to advance their cause and preserve their homes and neighbourhood. ${ }^{11}$ In August 1988 over one thousand citizens and activists demonstrated against the music project, and, after continued and increasingly violent attacks on the building site and equipment, on 13 September 1988 it was announced that the Phantom musical would be moved to another location. ${ }^{12}$ Hans-Peter Strenge, the Bezirksamtleiter at the time offered the Flora group a six week contract to use the space as a culture centre, and when this lease expired on 1 November 1989, the activists stayed, declaring the site occupied. ${ }^{13}$ The mayor feared continued civil unrest, as support was widespread, and even the police had cooperated with citizens during the initial campaign. ${ }^{14}$ To avoid escalating violence, he decided not to clear the Autonomists from the building, and the squat remains to this day. The Autonomists who became the Rote Flora milieu over the next few decades differentiate their political practice largely through the use of limited political violence, and by themselves being 'Militant'. One aspect of their 'Militanz' includes the mass marching of black-clad Autonomists who form the hard inner core of a demonstration. This so-called 'Black Block' is traditionally formed of those Autonomists willing to use 'Militanz', or morally limited political violence, as this article will elucidate.

While objective scholarship on this post-1977 Autonomous 'Militanz' is relatively sparse, the few existing sources have generally differentiated it as 1) an act of mass symbolic violence or sabotage against objects (via rejection of the state monopoly on violence); and/or 2) a resistant subjectivity and attitude. ${ }^{15}$ Within this general alignment, sources vary greatly as to specifics. Taking this complexity into account, Sebastian Haunss offers a fourfold breakdown of 'Militanz', including, in terms of group 
practice: 1) mass 'Militanz'; 2) group sabotage against symbols; 3) militant cells; and 4) armed struggle. ${ }^{16}$ In terms of individual practice, he further defines it as a visible (and experience-based) expression of being radically opposed to a system, which is 1) practised concretely; 2) reacts actively to repressive state policy; but also 3) contains a performative component allowing actors to self-style themselves. ${ }^{17}$ His breakdown encompasses both individual and mass actions, as well as subjectivity-formation and physical acts of sabotage, and he extends his schema to the actions of guerrilla and terrorist cells, such as the RAF.

However, with respect for Haunss, this article will exclude the attacks and murders of the RAF and militant terrorist cells from the same category as Autonomist 'Militanz' post 1977. After conducting 32 semi-structured interviews during 2015-2018 with Autonomist members active in an organisational role in the Hamburg Rote Flora milieu since 1989, my research concludes that nearly all participants vehemently maintained this distinction against the RAF as a strict conceptual boundary, arguing some version of the following:

Dann ist es ja so, dass die Autonomen immer gesagt haben, das ist ja auch der Unterschied zur RAF meinetwegen, dass Gewalt sich nicht gegen Menschen richten darf, sondern dass Gewalt nur gegen Sachen sich richten darf. Symbolisch. ${ }^{18}$

While violent terrorist attacks were practised by a few militant groups in the 1970s, the Autonomist practice of 'Militanz' hinges on violence against objects but explicitly not against humans, thus excluding 'militant cells' and 'the armed struggle' from its definition. This article will therefore account for mass and individual 'Militanz' after 1977 in the Autonomous movement as both a radical attitude and a physical act of limited violence. It acknowledges that the actual practice of 'Militanz' adapts and evolves during each subsequent generation of Autonomist activism, and that its specific manifestations vary over time. ${ }^{19}$ However, I offer a definition of post-1977 'Militanz' as: a form of direct action or symbolic identity-formation, which physically or performatively interrupts and disrupts forces considered to be oppressive, maintaining the potential of using violence, and justifying this via claims to moral righteousness, but specifically only when applied to physical objects and symbols rather than people. 
Participants in the Rote Flora Autonomist movement offer an even narrower definition of 'Militanz', in contradistinction to 'Gewalt', using the particular criterion of morality. While the 32 interviewees each offered varying perspectives on 'Militanz', they tended to agree with the unofficial speaker Andreas Blechschmidt's definition of 'Militanz' as 'Gewalt mit moralischem Recht'. ${ }^{20}$ This 'Militanz' is only permissible as self-defence ('Selbstverteidigung') and counterviolence ('Gegengewalt') against structural violence or other righteous causes, such as hindering the marches of Neo-Nazis for example. ${ }^{21}$. Blechschmidt contrasts 'Gewalt' as structurally false and unjust because it lacks what he believes to be the 'correct' moral motivation. In his words:

Insofern würde ich sagen, dass wir keine Gewalt ausüben, sondern Militanz, die natürlich gewalttätig ist. Für mich ist Gewalt etwas Unreflektiertes und ohne Kriterien [...] Für mich ist Militanz Gewalt mit Moral, während Gewalt strukturell falsch sein kann und ungerecht. ${ }^{22}$ Blechschmidt's distinction between 'Militanz' as 'Gewalt mit Moral' and 'Gewalt' that is 'ungerecht' indicates the stark distinction between the two concepts in Autonomist ideology and practice, and forms the kernel of the Flora group's practice and justification of 'Militanz' using violence.

\section{'MILITANZ' AS COUNTERVIOLENCE}

The Autonomists set moralised 'Militanz' in contradistinction and resistance to state structural violence, which they consider to be the opposite form of 'Gewalt'. As Pia, a participant in the movement from 1989 to the present, explains: 'Gewalt ist für mich mittlerweile auch total negativ konnotiert, Gewalt ist $[\ldots]$ strukturelle Gewalt'. ${ }^{23}$ Anna, an Autonomist who participated in the occupation of the Flora and remained active until the late 1990s, agrees: 'ich sag mal, dass es unterschiedliche Formen von Gewalt gibt: also, so etwas wie eine strukturelle Gewalt'. ${ }^{24}$ As Galtung $^{25}$ and later Žižek ${ }^{26}$ and Balibar ${ }^{27}$ have theorized, structural violence includes the forces of class-based, economic, linguistic, social, cultural and even ecological control that act upon individuals and prevent them from obtaining access to decision-making power in their lives, or as Anna summarizes: 'Menschen auch klein zu halten, arm zu halten, ungebildet zu halten'. ${ }^{28}$ This 
structural violence is associated almost entirely with the state, and is considered by Autonomists to be a form of dominating hierarchy, including: Racism, Sexism, and oppression against individuals. As Anna explains:

Und das ist so der Grundgedanke gewesen, dass es so verschiedene Arten von Gewalt eben halt gibt und dass die Gewalt eigentlich vom Staat ausgeht. Dass man in ein Leben reingedrückt wird, mit Gewalt reingedrückt wird, das man eigentlich nicht leben möchte, und da drin dann noch andere gesellschaftliche wie sexistische Gewalt, rassistische Gewalt, wie solche Sachen wirken. ${ }^{29}$

The Autonomist conception of 'Militanz' is theorized as an antidote to and rejection of this structural violence, or, as Max summarises: 'Militanz ist quasi das direkte Gegenprojekt' ${ }^{30}$ Another Autonomist goes on to explain that the practitioner of 'Militanz' must reject the concept of violence altogether. 'Das ist Militanz. Gewalt ist das, was die anderen machen und wir sind militant. Also! ${ }^{31}$

\section{RESISTANCE AND SUBJECTIVITY: THE 'THREE ANTIS'}

This particular Hamburg Autonomist practice of 'Gegengewalt' as a direct 'Gegenprojekt' is historically and theoretically grounded in the early 1990's concept of 'Dreizueins' or the 'three Antis'. ${ }^{32}$ According to a widely circulated article by Klaus Viehmann, often cited by movement participants, these include Racism, Sexism, and Capitalism, (as well as Anti-Semitism, Fascism, class, and oppression, which are often substituted interchangeably). ${ }^{33}$ This concept is distinguished from earlier Left-wing 'Gegengewalt' by the argument that the Left had historically focused on Capitalism/class to such an extent that they neglected to notice the Racism and Sexism that had begun to contaminate their own selves, communities, beliefs, and practices. After 'Dreizueins' circulated widely in the Autonomist scene, and in the historical context of the end of the Marxist revolutionary vanguard in 1977, effecting political change transmuted from an outwardly facing to an inwardly facing approach. The autonomist subjects became concerned with the creation of themselves as militants who resisted oppressive societal influences (via adherence to the Antis). For example, Hans describes how the men in the Flora met at anti-sexist 
men's cafés in the early to mid 1990s in order to examine their own behaviour in a group therapy setting, and to identify and eliminate any sexist thoughts or behaviours. ${ }^{34}$ Such actions were believed to make the Autonomist subject resistant to Sexism, and were therefore also a crucial part of forming the self as resistant. Clara discusses the difficulties of this continual moralised process of self formation, and explains that even though she writes about the ideal militant subject, she herself could not always live up to these principles, and so must continually 'develop herself' towards this ideal behaviour ('es ist noch ein weiter Weg, mich dahin zu entwickeln). ${ }^{35}$ This emphasis on continual self-surveillance and self-policing points towards the cultivation of a resistant subjectivity; conceptually inherent to being a militant subject.

While practicing these 'drei Antis', the Flora Autonomists deemed their own militant actions to be morally superior in the historical post-77 context wherein violence must never be used against people, but could only be directed against things or symbols indicating Racism, Sexism, and/or Capitalism. Even people who represented these 'evils', such as policemen, could only be attacked symbolically, otherwise the action would cross the boundary between righteous 'Militanz' and non-righteous 'Gewalt'. Claude offers an example of a generalised situation during a demonstration when an Autonomist has the option to leave a police officer who is fallen and thus no longer a threat, or to assault him. He cites this moment as 'den Unterschied zwischen 'Militanz' und Gewalt'. ${ }^{36}$ This distinction rests on the fact that even a police officer who symbolically represents Fascism or Capitalism may not be injured unless he is acting in that regard. It also distinguishes the Autonomists from the earlier RAF assertion that police are 'Swine' and not human. ${ }^{37}$ Unlike the RAF, for the Autonomists, to attack any person, even a police officer in such a scenario, would still be unjustifiable violence, rather than an act of 'Militanz' or self-defence. Claude also explains that

es gab doch so einen sehr starken Gedanken, dass Militanz vor allen Dingen auch bedeutet, militant gegen Sachen zu sein, nicht gegen Personen [...] Also, wenn man irgendwie, wenn irgendwelche Leute irgendwo was angezündet haben, da musste halt klar sein, da darf niemand verletzt werden. ${ }^{38}$ 
For example, when imprisoned in 1992 on charges of laying concrete blocks on train tracks, two Autonomists based their legal defence upon the logic that that they would never have performed this action, because 'eine Aktion, die irgendwelche Menschen, in irgendwelchem Zug, zu irgendwelcher Zeit gefährdet, wäre das genaue Gegenteil zu unserem Denken' and that any assault was thus completely incompatible with their moralised practice. ${ }^{39}$

It is important to note that these Autonomists do categorically refuse the state monopoly on violence, and therefore are willing to use force when necessary. Flora plenum members Hans-Martin and Andreas Blechschmidt both explain that Autonomists refuse the state monopoly on violence because they consider it to be unjust and immoral. ${ }^{40}$ Hans-Martin further clarifies that Autonomists believe that it is always just or righteous to combat Fascism and Anti-Semitism, and in any situation where state policy might enable these beliefs, the Autonomist has a moral duty to oppose them as well. ${ }^{41}$ For example, in 1992 many Autonomists from the Flora travelled to Rostock to interrupt Neo-Nazi attacks on Vietnamese immigrants' houses, when police and firemen were not reacting quickly. ${ }^{42}$ In another instance during the mid 1990s, a well-known Neo-Nazi moved into the social housing built behind the Rote Flora. The Autonomists organized demonstrations and interventions to demand that he leave their neighbourhood, as they felt the presence of a Fascist could not be tolerated in their so-called 'protected zone' ${ }^{43}$ They justified these actions as moral counterviolence, grounded in the 'drei Antis'.

\section{'MILITANZ' AS ATTITUDE IN EVERYDAY LIFE}

In addition to being an action, 'Militanz' is also the attitude of constituting and forming oneself as a resistant subject, refusing the norms of the Capitalist state and everyday life, by which Autonomists conceptually distinguished themselves from normal state citizens. Instead, the Autonomist lived as much as possible in a counter cultural scene, including alternative modes of consumption, particularly: libraries, book and record stores, info shops and bars. ${ }^{44}$ Building upon the 1968 concept of the personal as political, (and relying on thinkers such as Henri Lefebvre, ${ }^{45}$ whose Criticisms of Everyday Life had been published in German in 1974), 'everyday life' became the site of political resistance, as John Roberts has explained 
in detail. ${ }^{46}$ This represented a transition from the 1970 s practices of political violence and terrorism, as the Autonomist no longer sought to instigate a societal revolution, but rather occupied houses and other city spaces in order to create micro-societies within which they could live everyday life in an alternate manner. For example, a militant Autonomist might refuse to obey laws they consider to be unjust, such as the 1992 decision to stop registering their yearly street festival, which they justified by arguing that they had the right to use 'their' streets. ${ }^{47}$ Other examples include the strict rules practised within the Rote Flora, such as a prohibition against drugs, hard alcohol, and in many instances, non-vegan food. These daily lifestyle choices may not resemble the violent threat typically associated with Autonomist 'Militanz', but they were also an important part of the everyday life espoused by this ideology.

More visibly, dark shabby clothing and the Black Block costume of sunglasses and hoods were also used to physically and symbolically distinguish the Autonomist militant subject from the "mainstream", both individual and en masse. This Black Block identity formation can be best understood through the example of Vermummung, or the wearing of a balaclava. In a way, this practice could represent both types of 'Militanz'; it is both a threat of real counterviolence against the forces of structural violence, and a form of individual subjective self-distinction as a refusing subject. However, as both posturing act and militant attitude, it nonetheless remains primarily a symbolic form of being a resistant subject who is willing to threaten to use violence, without necessarily engaging in it. Rainer Paris often refers to this attitude as the threat of 'Militanz ohne Militanz'; the menacing image of the resistant self, constituted as someone capable of using violence, but not actually applying it. ${ }^{48}$ This representation indicated a particularly 'aggressive distinction' of the Autonomist as one who refuses the state monopoly on violence, without necessarily contesting that force. ${ }^{49}$ As the Flora's unofficial speaker Blechschmidt explains:

Vom Habitus sind bei einer autonomen Demo alle vermummt. Und ich würde sagen, dass man da mit Bildern spielt [...] Es ist oft nur ein Symbol, weil bei der militärischen Zusammensetzung mit der Stadt, würden wir auf jeden Fall verlieren. ${ }^{50}$ 
In his semi-autobiographical novel, the Autonomist Tomas Lecort describes this symbol as physically establishing the 'Gefühl der Stärke', ${ }^{51}$ in which the masked 'radiant heroes' ('strahlende Helden') symbolically reclaim power by using the anonymity of the balaclava to act offensively, rather than defensively, and feel protected and defended enough to realize and defend their own 'symbolische Selbstermächtigung,. ${ }^{52}$ Autonomist Samuel agrees, and describes the 'Gefühl von größerem Mut und größerer Freiheit' that he experiences when masked. ${ }^{53}$ This 'empowered' subject is not necessarily engaged in acts of violence, but rather constitutes himself or herself as one who feels strong and free enough to potentially do so.

\section{'MILITANZ' AS ACT}

These militant identities are put into practice in a wide array of forms, especially because they are individually defined by different individuals and groups in what one participant describes as a 'tausende Varianten' possible ${ }^{54}$ However, despite the wide range of applications, she specifies that 'Militanz' is never just 'Gewalt', nor is it only just words, but rather it is always rather a specific, conditioned action concerned with 'Intervention'. ${ }^{55}$ The idea is that one uses physical action to resist and interrupt that which one perceives to be wrong, in the spirit of Ulrike Meinhof's famous declaration of 1968 that:

'Widerstand ist, wenn ich dafür sorge, daß alle andern auch nicht mehr mitmachen' ${ }^{56}$ In the post-77 Autonomist context, this historical stance is coupled with physical action that is strictly limited by the Antis. Faced with perceived injustice, the Autonomist not only engages in symbolic or verbal actions, but also takes the next physical step to intervene, despite laws to the contrary. As Albert explains: 'wir gehen einen Schritt weiter, das ist zwar jetzt nicht erlaubt, aber wir nehmen uns das Recht, dieses und jenes zu machen, auch wenn es nicht erlaubt ist' ${ }^{57}$ This transgression 'einen Schritt weiter' past the borders of what is legal and permissible differentiates 'Militanz' from peaceful protest, although both seek to intervene against perceived injustices. At the same time, stopping before the border of violence against people, even if they are representatives of a perceived unjust state, differentiates 'Militanz' from 'Gewalt', and the Autonomists' interventions from the violence of the RAF. 
Another important consideration of 'Militanz' is that it is never only an identity or discourse, but rather must also at least threaten engagement in a situation where political communication and negotiation are considered to have failed. For example, petitions, posters, flyers, and other purely discursive methods of resistance are not categorised as 'militant' by Autonomists. ${ }^{58}$ They are considered to be peaceful methods, whereas 'Militanz' 'braucht auch eine materielle Ausdrucksform' as Autonomist Max stipulates. ${ }^{59}$ This is especially applicable for the Autonomist ideology in a neoliberal democracy, where citizen voices can be overshadowed by corporate interests, leading disillusioned activists to conclude that violence is the only possible method for participating in the public sphere. For example, demolition of the Rote Flora theatre was contested for over two years using non-violent methods such as petitions or peaceful blockades. However, the eventual meeting granted to 250 citizens with the Senate on 17 March 1988 and the invitation for an alternative 'Nutzungskonzept' from the Autonomists on 20 April turned out to be only empty but calculated political gestures, as the building contract had already been signed. ${ }^{60}$ Frustrated that democratic methods were thwarted and their voices ignored, the citizens and Autonomists ultimately squatted the theatre by relying on the threat of violent force. Regarding this occupation, Claude explains: 'Mit friedlichen Protesten hätte man das nicht hingekriegt, das hat man nur hingekriegt, weil man so den Preis hochgetrieben hat, dass sie einfach sich nicht getraut haben, das durchzusetzen'. ${ }^{61}$ While the 'price' of ignoring peaceful protest was 'paid' by the Senate to establish a profitable music theatre, the 'price' of violence, in this case, was considered to be too high. Andreas agrees, and explains:

So ist die Flora auch erkämpft worden, durch Besetzung [...] Demonstrationen, Angriffe auf Polizeiwagen. Das war allen in der Flora klar, dass man nicht gewaltgeil ist, aber dass Gewalt ein legitimes Mittel in der politischen Auseinandersetzung ist. ${ }^{62}$ Both activists believe that the Flora as a political project would not have been possible without militant action, and invoke two years of failed peaceful methods to support this argument. Anna, who was active in 1988-89 during the community campaign against restructuring, agrees, and explains that militant action was the only way of being taken seriously in their campaign against gentrification, which the Autonomists interpreted as structural violence akin to Racism or Sexism: 
in dem Moment, in dem du friedlichen Protest ausübst, wirst du ganz schnell vereinnahmt, nimmt dich auch keiner ernst. Und erst in dem Moment, in dem du selber gewalttätig bist, wirst du erst als ernstzunehmender Akteur wahrgenommen. ${ }^{63}$

Anna, Claude and Andreas all would rather use peaceful methods to communicate, but in the situation where peaceful communication was ignored, the only remaining tool with any political impact was 'Militanz', the next step ('Schritt weiter') when all other tactics had failed.

\section{STRAGEGIES OF 'MILITANZ': SELF-DEFENCE}

One of the most critical and yet often overlooked aspects of 'Militanz' as action is the pragmatic need for self-defence when a subject is participating in a demonstration. Claus explains that the clothing or accessories that some scholars such as Dieter Rucht might dismiss as merely a ritual or fetish ${ }^{64}$ are actually pragmatics against the reality of a charging police officer. ${ }^{65}$ This resistance to power ('Gegenmacht') was often less of a political stance and more an issue of self-defence, as Sophia explains: 'Militanz in der Flora [...] hat für mich mit Verteidigung zu tun' ${ }^{66}$ This defence is both ideological protecting and defending either the culture centre, or other vulnerable groups such as immigrants - as well as physical self-defence of one's body against police batons. Walter explains that militants lock arms in a blockade not only for the symbolism of remaining together, but more immediately to slow the police and prevent them from physically prying apart their human blockade. ${ }^{67}$ Claude also rejects the argument that this is highly ritualised or theatrical, arguing that the symbolism of black masks and helmets has more to do with protecting oneself against identification, and shielding one's head from police batons:

Ich habe das immer als eine Notwendigkeit betrachtet. Sonst zieh ich einen roten Pulli an, [aber] da wirst du gleich identifiziert. Man vermummt sich, weil man halt die ganze Zeit fotografiert wird. Man hat einen Helm auf, weil halt die Knüppel da kommen. ${ }^{68}$

\section{MOTIVATION OF 'MILITANZ'}


What underpins all of these elements of 'Militanz', whether symbolic, subjective, or pragmatic, is the moralized motivation to fight against perceived injustice. This reasoning was debated extensively, often in numerous hours-long plenums and working groups. For instance, Sebastian Haunss has analysed the debates over 'Militanz' from 1988 to 2001 and identified 350 published pieces in the Antifascist magazine Interim. ${ }^{69}$ At least another 55 articles and discussion pieces were published in this same magazine between 2001 and $2004,{ }^{70}$ but these represent only a tiny fraction of the wide-ranging nature of this debate in various other published sources over the more than 40 years that the 'Militanz Diskussion begleitet autonome Politik'. ${ }^{71}$ However, while 'Militanz' is endlessly debated and justified within specific scenes or communities, its application through the use of even symbolic violence is anything but clear. While Blechschmidt's definition of 'Gewalt mit moralischem Recht' might seem obvious to him, in effect this can also result in a system of violent attacks on anything that a small group of vigilantes deems to be unjust. $^{72}$ Autonomist Alfred, who was himself subject to attacks and temporarily banned after false accusations were levelled against him in the mid 1990s, voices this concern:

Wir sind die Macht! [...U]nsere Militanz ist moralisch abgesichert, aber das hat nichts mit Gewalt zu tun. Aber ich würde da noch ein paar Fragezeichen dahinter setzen, weil wer definiert denn das? Die Moral...Das ist halt schwierig. ${ }^{73}$

As he points out, the question of defining morality is a universalising project, which seems incompatible with a group dedicated to maintaining a counter-cultural, radically individualist, even autonomist view on broader society. Furthermore, while this specific Autonomist group may define Neo-Nazis, Fascists and neoliberal Capitalists as the enemies of the Left-wing Schanzenviertel-residents and of moral righteousness more broadly, other groups may have a distinctly different perspective on their own 'Antis'. The next section of this article will apply this discussion of 'Militanz' to the riot that broke out in Hamburg during the July 2017 G20 Summit. It will identify the various groups who participated, and point to the conceptual contradictions and conflations of 'Militanz' that became evident during this event.

\section{THE ANTI-G20 RIOT: CHRONOLOGY}


During the July 2017 protests against the G20-summit in Hamburg, almost 100,000 people participated in at least 25 registered protests, one of which was co-organised by members of the Rote Flora. Unlike these legally registered demonstrations, the riot that erupted on Friday 7 July was not planned, but rather emerged from a wide combination of factors, including the typically raucous 'partyatmosphere' in the Left-wing Schanzenviertel on any Friday night. ${ }^{74}$ Politically the riot was also fuelled by widespread anger at the 'Welcome to Hell' demonstration, which was attended by about 76,000, but was unable to proceed more than a few meters. It also stemmed from frustration at the feeling of living in a 'police state' for weeks before the $\mathrm{G} 20^{75}$. This impression was encouraged by the presence of an additional 31,000 police officers, helicopter patrols over the city, random checks, and road closures in the restricted zone, which included much of central Hamburg. It was also a matter of many different groups and the remnants of several large demonstrations coalescing at the same time in the same place. On Friday at around 15:00 more than 10,000 people gathered on the Reeperbahn for the planned peaceful blockade 'Colour the Red Zone'. ${ }^{76}$ According to one participant eyewitness, a simultaneous demonstration a few blocks away at the river-front terminal Landungsbrücken faced water cannons and police horses, resulting in barricades being erected between Fischmarkt and Landungsbrücken around 17:30. ${ }^{77}$ Participants from both demonstrations clashed with police throughout their marches, but eventually made it to the Elbphilharmonie by 18:20, where they prevented a delegation from entering the music hall at 19:30, before heading to the Schanze. At 19:00 2000 cyclists began a 'Colourful Mass': a bicycle protest to symbolically reclaim the space of the city streets. ${ }^{78}$ At 20:00, a militant Communist demonstration planned on the Reeperbahn was cancelled. ${ }^{79}$ One anonymous speaker from this splinter group unapologetically stated that the group planned to use violent methods, ${ }^{80}$ and the participants who acknowledged this fact and still gathered joined with some of the remaining 10,000 participants from the afternoon demonstration and drifted towards the Schanze, where fighting between police and protestors had been reported in front of the Rote Flora. ${ }^{81}$

One anonymous activist reports crossing the police line around the Schanze, at the intersection of Neuer Pferdemarkt Schulterblatt and Schanzenstrasse around 21:00, while police were distracted by a 
large group of black clad figures throwing stones and bottles. ${ }^{82}$ He reports that by 21:30 burning barricades surrounded entrances to the neighbourhood, and police forces were beaten back and forced to withdraw. ${ }^{83}$ Around the same time the Rewe grocery store and the Budnikowsky pharmacy were looted by both masked, black-clad individuals as well as regularly dressed people. An on-site taz correspondent reported that by 21:50 burning barricades surrounded entrances to the Schanze, and although water cannons were used twice to extinguish them, they were simply relit by rioters. ${ }^{84}$ The correspondent described the scene as 'eine andere Welt', full of black flames and running figures clad in black. ${ }^{85}$

\section{THE MULTIPLICITY OF THE RIOT: WHO PARTICIPATED?}

Schanze business owner Alvaro Piña reports a similarly chaotic scene, but specifies that, like many riots, this one was not perpetrated by a homogenous ideological singularity, but rather by many groups with often contrasting motives. ${ }^{86}$ A Spiegel reporter paints a similarly varied picture of this multifaceted conglomerate:

Die Grenzen zwischen friedlichen Demonstranten, Krawalltouristen und Militanten verwischen [...] Dazwischen immer wieder kleine Gruppen Vermummter - ganz in schwarz und mit Handschuhen, um Steine zu werfen. Die Versammlung auf der Kreuzung vor den Landungsbrücken wirkt friedlich und fröhlich. Kinder sind dabei und Ältere. Musik spielt, einige spielen Fußball. Zugleich wird jeder Steinwurf der Autonomen mit Gejohle und Applaus bedacht. ${ }^{87}$

Overall, it was a chaotic environment where children, the elderly, and peaceful protestors mixed freely with curious onlookers, anarchists lighting fires, and masked militants throwing stones, all surrounded by thousands of onlookers holding cameras. Many so-called rioters were simply ordinary Hamburg citizens who came to watch the spectacle or eat street food in the festive atmosphere. Others were black masked militants from Germany or abroad. The only factor not present was homogeneity. To explain this multifaceted conglomeration, this section will outline a few of the most prominent sub-factions who took part in the event. 


\section{Festival Goers}

The first contingent was made up of those who perceived the riot as a festival. ${ }^{88}$ Piña reports that after police were beaten back from the Schanze, thousands of onlookers, 'Voyeure und Gaffer, mit Handys' came out to watch the spectacle. ${ }^{89}$ This party atmosphere heightened around 23:00, when 2000 cyclist demonstrators rode en masse into the area, wearing colourful clothing and heightening the sense of celebration. One Autonomist reports: 'Many businesses were open, packed with people buying falafel or drinks. As people lined the streets, cheering at the arrival of the bicyclists, it could have been a familyfriendly festival' ${ }^{90} \mathrm{He}$ also recalls: 'The atmosphere was relaxed. People were standing together, admiring the fires, talking and eating and drinking, ${ }^{91}$ The $t a z$ correspondent agrees: 'Die Straßen sind voll von Leuten: bunt angezogen und mit Bier in der Hand oder schwarz und vermummt', and 'Hunderte Schaulustige verfolgen die Szene', contributing to the festival atmosphere, and recording endless video and camera footage. ${ }^{92}$ However the correspondent specified that: 'auf der Straße sind kaum Autonome, sondern "ohne Ende Partyvolk". ${ }^{93}$ It is therefore important to note that these celebrating 'Gaffer' were not necessarily part of the Autonomist Black Block, even if some might have worn balaclavas. Rather, such a festive assortment indicates the multifaceted nature of such protests, during which a game of football might occur simultaneously with stones being thrown or barricades burned, while tourists and curious citizens filmed the entire raucous scene on their cellphones. No single group or ideology dominated this tableau, and according to the taz, the only group conspicuously absent in significant numbers were the German Autonomists. ${ }^{94}$

\section{'Riotkids'}

The second facet was more violent, but that still does not therefore necessarily mean they were a coordinated group of German Autonomists. According to the witness Piña, they were primarily 15-20year-old 'Mackermilitants': youths from the suburbs, eager to set fires or smash a window for the thrill of breaking the law, but without any political motivation behind their actions, or any understanding of the 
habitus of the radical left. ${ }^{95}$ Describing this wave of participants in the riot, he differentiates them strictly from the Black Block and the curious festival onlookers (Gaffer), and explains that:

dann, in diesem Windschatten [der Gaffer] kamen die Kids. Dann ging es los mit den Plünderungen, der Randale. Viele migrantische Kids [...] Das ist etwas, das man sich mal anschauen sollte: Was da für ein Gewaltpotenzial ist, für eine Wut, die man auch mal erkennen muss. Aber eben nicht erkennen kann, wenn man alles nur unter schwarzer Block zusammenfasst. ${ }^{96}$

Many news outlets carried images of these young men eagerly photographing themselves in front of burning barricades, flexing their muscles and often shirtless, and Piña recounts reports that many were instantly uploading videos of their acts of bravado to social media, (which is taboo in Autonomist circles). ${ }^{97} \mathrm{He}$ also recounts drunken youths throwing bottles off roofs, with no coordination with the groups on the ground, or thought for whom they might hit (which again differentiates them from traditionally well-organised Autonomist cells). Their presence was not a new phenomenon: 'Mackermilitants' or 'riotkids' have been part of the debate on radical Left-wing violence for years, and the 'sexy allure' of hovering near a protest is well documented. ${ }^{98}$ While these 'kids' might come to riots dressed in black to mimic 'dangerous' Black Block garb, that does not automatically entail membership in the Autonomist political milieu or the Black Block.

It is interesting to note that Piña, himself an immigrant, specifically mentions the many 'migrantische Kids' who took part in the riot. Historically the Autonomist milieu in Hamburg has remained almost entirely Caucasian, and although marches and campaigns for solidarity with refugees are common, there is very little participation from immigrants. ${ }^{99}$ However, refugees and migrants did attend the anti-G20 protests for what I hypothesize to be both political and apolitical reasons. Politically: Katja, who works for a non-profit social justice organisation, explains that many refugees were frustrated by the large police presence in the weeks before the G20, which effectively increased the racial profiling they faced daily. ${ }^{100}$ For many 'migrantische Kids' the riot may also have provided an outlet for the frustration they felt due to their 'stalled lives' in refugee camps, especially when those global leaders they held 
responsible for the wars and refugee crises that had displaced them were meeting just down the road to discuss their futures, but without their input. ${ }^{101}$ Apolitically: it remains important to recognize that many 'Kids', migrants included, rioted out of a sense of thrill at transgressing societal norms. While Piña is adamant that this is not always only 'apolitisches' but rather also indicates an expression of 'Ausgeschlossensein' and 'Ohnmacht', these are not therefore necessarily radically Left-wing or 'unter schwarzer Block zusammen[gefasst]'. ${ }^{102}$

In addition, many refugees and migrants, particularly from Africa, wanted to participate in the 'Welcome to Hell' demonstration as it criticised the wars in their home countries, but they did not understand that the march would never actually proceed. This foresight was common place in German Autonomist and activist circles, to the degree that even before the 'Welcome to Hell' march began Pia had already organized and registered the 'Helcome to Well' demonstration, which was designed to gather and reunite 'the scattered pieces of the broken demo' and allow them to continue marching along a new route. ${ }^{103}$ Sophia recalls speaking to the group of refugees with whom she volunteered, and was startled that so many planned to attend the protests. They did not understand that, despite the demonstration being legally registered to follow a route ending at the location where the G20 summit was held: 'es ging kein Weg daran, dass die Polizei diese Demo auch nur einen Millimeter marschieren lassen würde'. ${ }^{104}$ Similarly, Pia warned her refugee friends not to join 'the slaughter' that would inevitably occur 'within just a few steps' once the demonstration began, especially in the narrow corridor with three meter high concrete walls behind the St Pauli Fischmarkt, where it was scheduled to begin. This location would effectively 'trap' protesters between heavily armed riot-police wielding pepper spray and water cannons, forcing many to scramble over these walls and fall over the other side to escape. ${ }^{105}$ However, unaware of this impending 'trap', many refugees may have wished to contest international interference in their home countries, which seemed most feasible by joining the large demonstration advertising itself as contesting 'militarist interventions in Syria' and the lack of African input at the G20 summit. ${ }^{106}$ Therefore, when unable to march peacefully, many of those who had tried to participate democratically may have been left with the impression that violence spoke louder than words. As Piña argues, one must take into account the 
potential for violence in a frustrated group whose voices as refugees effectively had no outlet in the public sphere ('Was da für ein Gewaltpotenzial ist, für eine Wut, die man auch mal erkennen muss'). Some might have participated in Friday's riot out of this political resentment and sense of 'Ausgeschlossensein' from decisions regarding their own lives. ${ }^{107}$

\section{International Autonomists}

The third group is the most contentious, as it was made up of international Autonomists, many of whom likely considered themselves to be applying their own versions of 'Militanz'. Piña, himself a Spanish native speaker, notes that he saw small groups of foreign Autonomists, coordinated using hand signals, fully clothed in black, speaking Spanish, Greek, and Italian. ${ }^{108}$ Around 21:00 many such small groups were working their way up and down streets in the Schanze, systematically smashing all the windows, even those of residences and local businesses. Pia, herself a resident of the neighbourhood and the Rote Flora, and an organizer of one demonstration against the G20, refers to the group of masked activists who ran through the relatively wealthy Altona district setting dozens of cars on fire ${ }^{109}$, as well as committing other scattered attacks on cars between 6-7 July across the city. ${ }^{110}$ She categorically denied any German Autonomist connection to the burnt cars, explaining: 'burning cars, this is an action that people do in Greece' but not the Rote Flora, where they 'do a different type of politics'. ${ }^{111}$ Blechschmidt, unofficial speaker of the Rote Flora, also explicitly disavowed any such vandalism ('Autos von Anwohnerinnen anzuzünden') as inherently being against the Rote Flora group's particular version of Militanz’. ${ }^{112}$

However, the reality remains that dozens of privately owned cars were burnt, and mobs of black clad individuals, dressed like Autonomists, caused at least 40 million Euros of damage to homes, small shops and seemingly randomly targeted neighbourhood windows. To attribute the damage only to 'foreigners' risks falling into isolationist and xenophobic rhetorical patterns where irrational, 'hot blooded southerners' were prone to violence against 'reasonable Germans'. Such rhetoric is exactly how the Interior Minster of Baden-württemberg, Thomas Strobl, supported his demands that the German 
government establish a European-wide index of Left-wing extremists: 'um die marodierenden, herumreisenden linksextremistischen Gewalttäter im Grunde genommen schon an der Grenze abzufangen, so dass sie gar nicht bis zu solchen Ereignissen vordringen können'. ${ }^{113}$ The Federal Interior Minister Thomas de Maizière of the Christian Democratic Union (CDU) even declared that all of these violent protestors were 'genauso wie Neonazis und islamistische Terroristen' and should be treated accordingly. ${ }^{114}$ On the one hand, foreigners did attend protests in large numbers, and the Hamburger Morgenpost reports that 37 Italians and 25 French activists were detained. ${ }^{115}$ On the other hand, 158 Germans were also detained, suggesting that the rioters were not only foreigners. ${ }^{116}$ Therefore, while many Autonomists and rioters from other countries did apply a form of 'Militanz' that Germans from the Rote Flora would consider incompatible with their own practice, one cannot therefore engage in the xenophobic rhetoric that would solely blame these 'foreigners' for irrational violence and destruction. However, one also cannot absolve them of all responsibility either, and it is important to recognize that otherwise alien protest methods, such as burning cars, might indeed have been initiated by those who 'have a different riot culture' when practicing 'Militanz' as one Rote Flora participant explains. ${ }^{117}$

\section{German Autonomists}

Not all German Autonomists are associated with the Rote Flora or the distinct version of 'Militanz' espoused by that group, and it is entirely likely that many took part in the riot. However, as the taz correspondent reported, the Autonomists were a distinct minority amidst the 'Partyvolk' majority who perpetrated the riot. ${ }^{118}$ Others witnesses, such as Piña, recount seeing German Autonomists standing with neighbourhood residents to preserve residents' windows and the windows of a phone company from other masked rioters. For example:

Ich habe beobachtet, wie zwei Anwohnerinnen versucht haben, einen jungen Mann davon abzuhalten, mit einem Straßenschild eine Markise aufzustemmen. Als er nicht aufgehört hat, kamen Vermummte und haben ihm gesagt: „Du lässt das Ding jetzt sofort fallen!“ [...] Das hat er dann auch gemacht und ist weggerannt. ${ }^{119}$

Citing other examples, he describes Autonomists bringing bicycles safely back to a courtyard so they 
were not burnt, ${ }^{120}$ or helping a young woman who emerged from her house to ask youths to lay down the street signs they were using to smash her windows. ${ }^{121}$ Of course, Piña also qualifies these tales as not representing the norm, explaining:'und es wäre auch falsch, jetzt zu sagen, dass die Autonomen sich dort als Bürgerwehr oder Polizeiersatz aufgespielt hätten,' but he emphasizes that such instances of Autonomists protecting 'their' neighbourhood against marauding 'riotkids' and foreign groups did occur ('aber sie $g a b$ es'). ${ }^{122}$

A Flora Autonomist who took part in several demonstrations, including Thursday's 'Welcome to Hell', was adamant that the Friday riot was not instigated by those espousing the same motivations or politics as those who took part in the demonstrations: 'Als Autonom fühle ich mich nicht Teil von diesem Randale Quatsch am Freitagabend!"123 She differentiates between the Flora's practice of targeted 'Militanz' and what she believed to be either the foreign or 'riotkid' practice of indiscriminate violence and destruction that occurred, stipulating that: 'Es gab sicherlich keine deutschen Autonomen bei der Krawalle! ${ }^{, 24}$ Rather, in her opinion the riot was instigated by 'Riotkids,' 'Riottourists' and young men who were not part of the strict Autonomist group and its moralised version of 'Militanz'. ${ }^{125}$ A group of Italian Autonomists present at the G20 riots who released a statement taking responsibility for their role in the riot in fact openly acknowledge that the riots were not perpetrated by the same individuals in the Black Block who fought the police or marched in the 'Welcome to Hell' demonstration:

Der schwarze Block mit mehr als 3500 Leuten am Fischmarkt ist nicht derselbe, der in den Straßen von St Pauli gekämpft hat [...]Der Block wurde zerstört ${ }^{126}$ The taz correspondent present at the riot agrees, and explained that groups of German Autonomists built barricades and pushed police out of the neighbourhood before 21:00, but did not attack any shops or smash windows ('Aber es war kein einziger Laden angegriffen worden’.) ${ }^{127}$ The correspondent specifies that after their coordinated fight against police, the majority of them left the area ('hat der allergrößte Teil der Leute, die sich daran beteiligt hatten, das Weite gesucht'.) ${ }^{128}$ This suggests that the plundering of stores and indiscriminate smashing of windows an hour later were perpetrated by other groups. 


\section{Anarchists}

An anarchist group, writing in German but not associated with the Rote Flora, released a statement taking responsibility for the riot, and specifying that it was not affiliated with any political agenda, especially that of the Autonomists:

Dieses notwendigerweise gewaltvolle Abtrotzen eine Raumes, der nicht von den Bullen dominiert wird, welches einen grundsätzlichen Bruch mit dem bedeutet, was uns hier Tag für Tag auferlegt wird, hat nichts mit einer politischen Agenda oder dem Programm irgendeines Bündnisses zu tun, sondern mit der individuellen, völligen Wiederaneignung unserer Leben. ${ }^{129}$

They categorically refuse political agendas, and instead emphasise a typically anarchist intention to resist police control of the area in the days proceeding the riot. They frame the riot primarily in terms of fighting this police presence, in addition to a broader resistance against Capitalism and Racism as symbolised by the G20 gathering.

\section{Hostile Ideological Bodies: Right-Wing Hooligans and Police Provocateurs}

The enormous extent of this multiplicity is further compounded by the fact that right wing extremists and undercover police agent provocateurs took part in the riot. Two newspapers report NeoNazis and Right-wing extremists attending demonstrations and throwing bottles at riots, and typically Right-wing shouts of 'Deutschland gehört uns!' were heard at the Thursday 'Welcome to Hell' march. ${ }^{130}$ The Right-wing group ‘Hooligans gegen Salafisten' from Hannover, who caused extensive damage at riots in Cologne in 2014, also advertised their intention to attend the protests and were presumably there. ${ }^{131}$ Indeed, the Hamburger Morgenpost reports that at least a dozen right wing extremists participated in the riot, threw bottles at police officers, and attacked a group of Autonomists. ${ }^{132}$ Recorded footage also shows a plainclothes police officer, who had been actively rioting, shooting a live round of ammunition after the travel blogger 'Stefan Heber' was pushed to the ground by Autonomists, whom he had been filming even after they asked him to stop. ${ }^{133}$ Heber reports that the officer mistook him for 
another plainclothes colleague, and fired the shot to save him from the attack, and then helped him run away before asking him which undercover police contingent he was with. ${ }^{134}$ According to witnesses, four minutes later the undercover agent was surrounded by five fellow police officers who arrived in a car driving at high speed, and removed the undercover 'agent provocateur' from the kiosk where he had taken shelter, shielding him with their bodies and pepper spray as they retreated. ${ }^{135}$

\section{CRITICISMS AND CONFLATIONS: WHOSE 'MILITANZ'?}

A comment by one Italian group of rioters summarises the complexity of such a multifaceted event, as well as the impossibility of attributing blame to any one particular group:

Der Riot ist nicht und wird nie eine Art Orchester sein, dass in Einklang spielt, und bei dem alles so stattfindet, wie wir Aktivisten uns das vorstellen. Vor allem dann nicht, wenn ,Wir' eine politische Minderheit sind, die in diesem Kontext agiert. Der Krawall in der Schanze war chaotisch, weil zehntausende von Leute teilgenommen haben, weil er in jeder gepflasterte Straße des Viertels verbreitet wurde, überall. ${ }^{136}$

Responsibility for such an event can never be attributed to only one 'politische Minderheit' or group ideology, such as German Autonomie in the Rote Flora. However, the sheer multiplicity of groups engaged in black-clad militant violence, mimicking the tactics used by the Autonomists, raises the question of 'Militanz' itself, and particularly of its specific theoretical definition, when in contrast it is being applied in numerous different ways. One is therefore led to inquire how one can differentiate between a protest that is merely militant versus a 'legitimate' expression of 'righteous' 'Militanz' when the two forms appear to be identical. This concluding section will examine the Rote Flora group's version of 'Militanz', and interrogate their claims of effectively being the moral arbitrator of legitimate political violence.

\section{The Rote Flora on 'Militanz'}

The Rote Flora's perspective on 'Militanz' is presented by Blechschmidt's statement the morning 
after the riot:

Wir haben den Eindruck gehabt, dass sich hier etwas verselbstständigt hat und dass hier eine Form von Militanz auf die Straße getragen wurde, die sich selbst berauscht hat und das finden wir politisch und inhaltlich falsch. ${ }^{137}$

Despite this clear rejection of the violence that occurred, many politicians and journalists held him personally responsible for the riot, to the extent that Pia recounts being stormed in the Schanze by a mob of angry citizens demanding that she tell them where he was, so they could 'make him pay', ${ }^{138}$ and Andreas himself reports receiving death threats. ${ }^{139} \mathrm{He}$ was blamed as the co-organiser of the 'Welcome to Hell' demonstrations, to which invitations to 'Live the Resistance - join the black block' were distributed across Europe. ${ }^{140}$ However, despite his role in arguably enabling or at least assisting the conditions of the riot, Blechschmidt adamantly differentiates between 'Militanz' as a form of targeted protest against injustices such as war and hunger, and the riot that took place on Friday, involving attacks on houses, small businesses and automobiles. In his words:

Es geht darum, deutlich zu machen, dass die Verantwortlichen in der Messehalle als diejenigen, die für Krieg, für Hunger in der Welt verantwortlich sind, zu markieren. Aber es geht nicht darum, hier Budnikowsky-Filiale oder Autos von Anwohnerinnen anzuzünden. ${ }^{141}$

His differentiation between a 'Militanz' that contests societal injustice perpetrated by structural violence and one that is 'falsch' or intoxicated with itself (selbst berauscht), is justified, in his perspective, by the motivation and morality behind those actions. In the tradition of Autonomie practised in the Rote Flora, this motivation was intrinsically bound to the practice of being an 'Anti' subject, who opposes the three forms of oppression (Racism, Sexism, Capitalism) as described above. In theory, moralised 'Militanz' would, therefore, be concerned with contesting injustice (such as hunger, war, or Capitalism) but would never be practised against citizen's cars or attacks on locally owned pharmacies. So long as one is campaigning only against symbols of these evils, according to Blechschmidt's definition, one can differentiate righteous protests contesting the G20 from actions of the rioters who smashed resident's windows indiscriminately. 
However, the critical issue with this conception is the lack of positive formulation of what appropriate militant action is, rather than simply what it is against. An Autonomist militant might explain that 'Militanz' is the carefully determined practice of being an 'Anti' subject; one willing to use limited violence to resist the three evils (Racism, Sexism, and Capitalism) explained above, and that any demands

for affirmative principles therefore precisely miss the point, and are beyond the limits of this idea. ${ }^{142}$ Yet, this purely negating stance neglects any indication of what actions are morally permissible, as opposed to those that cross the line even for Autonomists. For example, English language maps titled 'Summitcity... know your friends and your enemies' were circulated in May of 2017 before the G20, marking 'rich' neighbourhoods with images of money bags. ${ }^{143}$ The map also specified appropriate protest targets, such as 4- and 5-star hotels, consulates, and the Elbphilharmonie concert hall. ${ }^{144}$ While the map indicated appropriate targets to 'be against' (via smashing windows, for instance), it did not specify which targets to protect. For example, it did not mark shops that were locally owned, or mention that the Budnikowsky pharmacy, which was plundered, was well-known for supporting refugees and offering them jobs. The map specified Left-wing centres but did not indicate that windows and residences in the Schanze have also always been traditionally 'off limits' for the Left, or that one should not throw stones when standing in the back of a marching group, so as to avoid hitting one's own fellow protestors. Such knowledge rather tends to be passed along informally in a subculture but is lost during an international riot scenario, especially given the conceptual absence of any concrete principles of what militant protest is 'for', rather than simply 'against'.

\section{Who has the Authority to Judge and Practise Militant Action?}

Another issue that arose during the riot was whether only the Rote Flora Autonomists can practise moral Militanz', or if other radical Left-wingers who are not Autonomists might lay claim to it as well. For example, one group of Anarchists at the riot, who were not part of the Rote Flora, and who smashed car and house windows, later reflected upon their own actions, and questioned the legitimacy of some of their own violence: 
Diese Scherbendemo selbst war in Teilen leider kein Ausdruck zielgerichteter Militanz, neben zahlreichen gut ausgewählten Geschäften fanden wir es richtig bekloppt, die Scheibe eines Linienbusses einzuschlagen und Fahrer und Insassen in Angst zu versetzen; auch etliche Kleinwagen waren wahllos. So müssen wir uns fragen: was sind die Limits und Kriterien unserer Aktionen $?^{145}$

This rhetoric of a 'goal-oriented Militanz' echoes that of the German Autonomists. The Anarchist group confirmed they had plundered the Budnikowsky, which supported refugees and was locally owned, and therefore did not fit the definition of an appropriate oppressive 'capitalist' target. However, they also criticized their own attacks on citizens' 'Kleinwagen' and the fear they caused in bus passengers, suggesting they understand some of the nuances of Militanz. ${ }^{146}$ In the same article they also declare: 'Widerstand und Militanz müssen zielgerichtet und vermittelbar bleiben'. ${ }^{147}$ While their violent destruction of inappropriate targets suggest they still had yet to determine the 'Limits und Kriterien' of their actions in order to practise Autonomist 'Militanz', this statement indicates that they nonetheless believed they had at least intended to practise some other type of 'Militanz'. Overall, their conflation of the two types, as evidenced in citizens' cars being attacked, and their statement that plundering local shops was a legitimate form of protest against the G20 and international Capitalism, ${ }^{148}$ raises the more pressing issue of their adaption of Autonomist 'Militanz' and their application of this concept, albeit in an entirely different direction.

In addition to different ideological groups applying the same 'Militanz' in distinct ways, some groups applied different ideas in nearly identical ways. For example, 'Mackermilitants' (hooligans or thugs) donned the same symbolic black attire as Autonomist militants, used many of the same techniques (barricades, throwing stones and bottles, or Molotov cocktails), moved in a block, and smashed windows but were decried by the Rote Flora Autonomists as not practicing real or proper 'Militanz'. While the Autonomists differentiate their practice using the criterion of motivation, one must inquire how a bystander is supposed to tell the difference between the two groups. 
This dilemma can also be exemplified by the action of smashing the windows of cars and/or burning them. This could be deemed 'Militanz' or not, depending on whether it was committed against cars owned by private citizens versus those perceived to be a luxury item. In fact, when citizens' cars were smashed and burned before and during the riot, Andreas Beuth, the former lawyer for the Rote Flora, differentiated this action from 'proper' Autonomist practice by stating: 'Wir als Autonome [...] haben gewisse Sympathien für solche Aktionen, aber bitte doch nicht im eigenen Viertel, wo wir wohnen, also warum nicht irgendwo in Pöseldorf oder in Blankenese?' (two rich city neighbourhoods) ${ }^{149}$ While bitterly contested and eventually retracted, ${ }^{150}$ his statement implied that burning privately owned cars in rich neighbourhoods was justified as 'Militanz', while doing it in poor neighbourhoods was not. Beuth was widely criticized by the media and politicians for blindly supporting political violence ${ }^{151}$, but within this debate, one largely overlooked aspect of his thought process was the question of who decides where one's “own” neighbourhood is. Despite Beuth's assumptions, the Schanze is no longer the poor neighbourhood that Autonomists defended in the 1980s, but rather home to incredibly high rents, tourist attractions, clubs and upscale restaurants, and expensive speciality boutiques. Another Autonomist, not affiliated with the Rote Flora group, raises this point in an article defending the riot, explaining: 'Zudem gab es gerade unter den sich beteiligenden Kids viele, deren Viertel eben nicht die gentrifizierte Schanze ist und die ihre ganz eigene Wut über die Verhältnisse mitgebracht haben'. ${ }^{152}$ Rather than the traditional Autonomist Rote Flora concept of fighting to protect 'their' Schanzenviertel, many rioters instead felt excluded from the gentrified neighbourhood, and held no affinity to it as 'theirs', thus making it an appropriate target by Beuth's logic.

Similarly, this conflation is demonstrated by the actions of foreign Autonomists, whom many criticised as rioting without espousing a proper political understanding of German Autonomous 'Militanz'. During the riot on 07 July, Greek, Spanish and Italian Autonomists were often blamed for systematically smashing the windows of residences in the Schanze, despite this being antithetical to the Hamburg Autonomist credo of protecting this neighbourhood. However, this accusation of improperly applied 'Militanz' is contestable when one considers that these foreign Autonomists might have been 
expressing their resistance against Germany as the economic heavyweight behind EU economics, and, therefore, the instigator of austerity politics. From such a perspective, their attacks upon German houses in a wealthy neighbourhood would in fact offer an ideal expression of 'Militanz' as defined by moral, anti-capitalist action against symbols of unequal distribution and financial oppression.

Similarly, one could argue that many of the 'riotkids' or 'Mackers' were actually seeking to express their anger at their exclusion from an oppressive political process led by an economic elite, which was also precisely why the Rote Flora was occupied in 1989. As business owner and witness Piña explains: 'Ich würde nicht sagen, dass die Ausschreitungen hier unpolitisch sind... Aber sie sind ein Ausdruck von irgendetwas: eine Ohnmacht, ein Ausgeschlossensein' ${ }^{153}$ These sentiments of powerlessness, anger, exclusion, and voicelessness in the political process become exacerbated by resentment towards police brutality over the preceding week. This is demonstrated by many marchers' inability to participate in their legal right to protest and demonstrate in the public sphere, especially after the police immediately attacked and broke up the 'Welcome to Hell' demonstration, to which many protestors had travelled across Europe. Civil liberties were suspended throughout the G20 and during the days leading up to it: police reserved the unconstitutional right to detain suspects indefinitely, without cause, and anyone could be searched at will. Thousands of travellers were turned away at the German border based only on suspicious appearance, inhibiting the right to free movement guaranteed in the European Union. The democratic right to assembly was denied in much of the city, and even small groups of more than three were considered a 'protest', and therefore subject to controls. ${ }^{154}$ Finally, the presence of 31,000 additional police officers in the city, the constant sound of helicopters patrolling the skies, and the aggressive attitude of this paramilitary presence left many angered and resentful at the impression that they were living in a police state. ${ }^{155}$ One group released a statement that they originally sought to protest against the politics symbolised by the G20, but ended up just revolting against the police ('Begonnen also Gipfel-Protest gegen G20, wird dies zur sozialen Revolte gegen die Bullenschweine'). ${ }^{156}$ This re-shifting of focus led many anarchists to prioritize the creation and defence of a 'police-free zone' in the Schanze for a few hours. While this riot was criticized as deeply apolitical, one group who participated counter- 
argues: 'on the contrary, nothing is more political than creating_such a space like this'. ${ }^{157}$ Their emphasis on symbolic spaces of resistance not only mimics the 1980s Autonomist creation of 'Freiräume' in squats $^{158}$, such as the Rote Flora itself, but also suggests that their violent riot was an equally political response to 'Ohnmacht', albeit in a different manner than that deemed acceptable by current Autonomist tradition.

Finally, other groups who rioted might not have been apolitical, but simply were not interested in the strict and complex Autonomist politics behind targeted militant actions, based on years of obscure internal debates. One anarchist group published a long article explaining their participation in the riots, in which they explicitly rejected the overly formalized Autonomist plenum-based decision-making process in favour of a privileging of immediacy and action: 'Du musst nicht seit Monaten auf irgendwelche Plena rennen, die dies und jenes absprechen und wieder verwerfen. Du musst nur auf das Telefon oder den TV schauen, kommen und mitmachen'. ${ }^{159}$ While these anarchists would be dismissed as 'Mackers' by Blechschmidt, who deemed their 'Militanz' 'politisch und inhaltlich falsch"160, such a statement indicates not ignorance, but rather disagreement with specific Autonomist methods rather than 'Militanz' itself. In conclusion, the riot raises the difficult question of whether one group can ever claim moral authority for violence, and how problematic this becomes when differentiating between otherwise nearly identical applications of 'Militanz'. Blechschmidt indicates the degree of this multiplicity when he explains: 'Die Militanz Diskussion begleitet autonome Politik seit 40 Jahren. Es ist klar, dass nicht jede militante Aktion in Ordnung ist'. ${ }^{161}$ However, while not every form of 'Militanz' is acceptable to him and his group, it is also important to note that a 40 -year old conversation must also contain many differing and contrasting perspectives, some of which were demonstrated during the multifaceted G20 riot. While Blechschmidt and the Rote Flora milieu cannot be held accountable for the actions of other activists, many of whom were not Autonomists, the riot also demonstrates that the Rote Flora Autonomists do not possess sole moral legitimacy for determining which militant actions are acceptable. This also suggests that the purely negative practice of 'Militanz' as a symbolic act and attitude requires further specific 
conceptual development by the radical Left, and cannot remain merely the performance of an 'Anti', lest all 'Antis' become acceptable militant violence, including those practised at the riot.

1 Claude, Interview with Author, 23 March 2016, Berlin. Please note that all interviewee names have been changed, with the exception of Andreas Blechschmidt, Hans-Martin, Hans-Peter Strenge, and Stefan Wartrin, upon their request. The author would like to thank Dr Eric Brewster, Professor Sarah Colvin, Dr Helen Roche, Dr Martin Ruehl, Dr Manu Signer, Dr Bart van der Steen, Ronja Wagner, Professor Jo Whaley, and Kathrin Wunderlich for their comments on early drafts of this article.

2 Rudi Dutschke, 'Gibt es eine Revolution ohne Gewalt?', Handschriftliche Aufzeichnung, Hamburg Institute für Sozialforschung (HIS)-Archiv, RuD, 310.04, p. 8f, cited in Wolfgang Kraushaar, hg. Die RAF und der linke Terrorismus Band 1, 2 vols, Hamburg 2006, p. 228.

$3 \quad$ Klaus Viehmann, Dreizueins, Hamburg 1990.

$4 \quad$ Westlichen Inneren Stadt (WIS) Papier, 1989, ASB 09.100; Rote Flora Plenum (Rote Flora organising body), 'Flora Besetzt', 1/11, (1989), p. 3. Archiv der Sozialen Bewegungen (ASB) 09.320; Former Bezirksamtleiter Hans-Peter Strenge, Interview with Author, 9 August 2017, Hamburg. $5 \quad$ WIS Papier, 1989, ASB 09.100.

$6 \quad$ Anonymous, 'Chronik', Neues Schanzenleben, August 1988, pp. 3-4.

$7 \quad$ Anonymous, 'Flora - was sonst', Neues Schanzenleben, August 1988, p. 3.

$8 \quad$ Ibid.

$9 \quad$ Flora Gruppe, 'Nutzungskonzept von BewohnerInnengruppen und Initiativen des

Schanzenviertels für das RESTFLORAGEBÄUDE also selbstbestimmtes und selbstorganisiertes Stadtteilkulturzentrum für alle und für das Floragelände als Freifläche zur Schaffung eines Volksparks', 1988, ASB 09.320.

10 Anonymous, 'Chronik', Neues Schanzenleben, August 1988, pp. 3-4. 

und Entwicklung eines Selbstorganisierten Stadteilzentrums', Unpublished Dipomarbeit, FachhochSchule Hamburg, 1992, p. 23, ASB 09.320, II.

12 Hamburger Abendblatt, 'Aus für die Flora', 13 September 1988, p. 1.

13 Former Bezirksamtleiter Hans Peter Strenge, Interview with Author, 9 August 2017, Hamburg.

14 According to a member of the citizen initiative engaged in the protests against the musical theatre. Stefan Watrin, Interview with Author, 10 February 2016, Hamburg.

15 Anders and Sedlmaier, 'The Limits of the Legitimate', in Willibald Steinmetz, Ingrid GilcherHoltey, Heinz-Gerhard Haupt, eds. Writing Political History Today, Frankfurt and New York 2013, p. 292.

16 Sebastian Haunss, Identität in Bewegung, Wiesbaden 2004, pp. 171-174.

17 Haunss, p. 125.

18 Anna, Interview with Author, 16 September 2016, Hamburg.

19 In fact, Leach's argues that this generational adaption is the reason Autonomie has survived for four decades. See Darcy Leach, "An Elusive "We": Antidogmatism, Democratic Practice, and the Contradictory Identity of the German Autonomen', American Behavioral Scientist, 2009, 52, (10421068).

20 Andreas Blechschmidt, Interview with Author, 17 February 2016, Hamburg.

21 Hans-Martin, Interview with Author, 27 December 2016, Hamburg.

22 Andreas Blechschmidt, Interview with Author, 17 February 2016, Hamburg.

23 Pia, Interview with Author, 27 September 2016, Hamburg.

24 Anna, Interview with Author, 16 September 2016, Hamburg.

25 Johan Galtung, 'Violence, Peace, and Peace Research', Journal of Peace Research, 6/3, (1969), (167-191).

26 Slavoj Žižek, Violence, London 2009.

$27 \quad$ Etienne Balibar, Violence and Civility, New York 2015. 
28 Anna, Interview with Author, 16 September 2016, Hamburg.

$29 \quad$ Ibid.

30 Max, Interview with Author, 6 September 2016, Hamburg.

31 Claude, Interview with Author, 23 March 2016, Berlin.

32 Walter, Interview with Author, 1 August 2015, Hamburg.

33 Viehmann, 1990.

34 These practices have a long historical precedent in the radical Left, particularly the group psychotherapy of the Kommune I in the 1970s. See Timothy Scott Brown, West Germany and the Global Sixties: The Anti-Authoritarian Revolt, 1962-1978, Cambridge: 2013, pp.51-58 for a detailed discussion. Hans, Interview with Author, 10 August 2016, Hamburg.

35 Clara, transcribed interview, in appendix, in Frigga Haus, Silke Wittich-Neven, und Victor Rego Diaz, 'Widerstand in Zeiten Neoliberaler Neuordnung - Träume und Utopien in der Rote Flora', Unpublished Projektarbeit, Fachhochschule Hamburg, 1999, p. 44, ASB 09.320.II.

36 Claude, Interview with Author, 23 March 2016, Berlin.

37 'entweder mensch oder schwein . . . entweder problem oder lösung'. Holger Meins, letter to Manfred Grashof (1 November 1974), in HIS Me,H/006,006; reprinted in edited form in Pieter Bakker Schut, hg., das info: briefe von gefangenen aus der raf aus der diskussion 1973-1977: dokumente, Kiel 1987, pp. 183-86.

38 Claude, Interview with Author, 23 March 2016, Berlin.

39 'aus unseren persönlichen und politischen Geschichte als Teil der radikalen Linken ist so ein Anschlag völlig ausgeschlossen [sic]'. Knud und Ralf, 'Untitled Letter from Prison', September 1991, ASB 02.670.

40 Hans-Martin and Andreas Blechschmidt, Interview with Author, 17 February 2016, Hamburg.

41 Hans-Martin, Interview with Author, 27 December 2016, Hamburg.

$42 \quad$ Pia, Interview with Author, 27 September 2016, Hamburg. 
43

In fact, a sign hung on the building specified: 'Die direkten Außenbereiche um die Rote Flora sind Teil des selbstverwalteten Autonomen Zentrums. Hier gelten unsere politischen Standards', including standards against: sexist or homophobic behaviour, Racism, Fascism, and physical violence. Rote Flora Plenum, Sign, Hanging in ASB.

$44 \quad$ For an extensive discussion of consumption and protest in the radical Left, see Alexander Sedlmaier, Consumption and Violence, Ann Arbour 2014.

$45 \quad$ Henri Lefebvre, Kritik des Alltagslebens, München 1974.

$46 \quad$ See John Roberts, Philosophizing the Everyday, London 2006.

47 Hans-Martin, Interview with Author, 27 December 2016, Hamburg.

48 Rainer Paris, 'Vermummung', Leviathan, 19/1 (1991), 117-129(118).

$49 \quad$ Ibid., (119).

50 Andreas Blechschmidt, Interview with Author, 17 February 2016, Hamburg.

51 Thomas Lecorte, Wir tanzen bis zum Ende: Die Geschichte eines Autonomen, Galgenberg 1992, p. 90.

52 Paris, (118-119).

53 Max, Interview with Author, 06 September 2016, Hamburg.

$54 \quad$ Pia, Interview with Author, 08 August 2017, Hamburg.

55 Pia, Interview with Author, 08 August 2017, Hamburg.

$56 \quad$ Ulrike Meinhof, 'Vom Protest zum Widerstand', konkret 5, (1968), (5).

57 Albert, Interview with Author, 12 April 2016, Hamburg.

58 For example, Autonomists do not consider a sitting blockade to be militant, whereas police do.

Therefore, in 2000 in Germany 3,173 militant actions were recorded by the 'Verfassungsschutz' (Office for the Protection of the Constitution), but Haunss argues that at least 979 of these would be considered peaceful by Autonomists. For the strikingly different definitions of militant action given by police versus by activists, see Haunss, pp. 169-170.

59 Max, Interview with Author, 6 September 2016, Hamburg. 
$60 \quad$ Flora Gruppe, 'Nutzungskonzept von BewohnerInnengruppen und Initiativen des

Schanzenviertels für das RESTFLORAGEBÄUDE also selbstbestimmtes und selbstorganisiertes

Stadtteilkulturzentrum für alle und für das Floragelände als Freifläche zur Schaffung eines Volksparks', 1988, ASB 09.320

61 Claude, Interview with Author, 23 March 2016, Berlin.

62 Andreas, Interview with Author, 17 February 2016, Hamburg.

63 Anna, Interview with Author, 16 September 2016, Hamburg.

64 See Dieter Rucht, ed., Berlin 1. Mai 2002 Politische Demonstrationsrituale, Opladen 2003.

65 'Und deswegen ist das gar kein Ritual, sondern eine ganz reale, konkrete Gegenmacht'. Claude, Interview with Author, 23 March 2016, Berlin.

66 Sophia, Interview with Author, 12 April 2016, Hamburg.

67 Walter, Interview with Author, 1 August 2015, Hamburg.

68 Claude, Interview with Author, 23 March 2016, Berlin.

69 Haunss, p. 172.

70 “'Militanz’ Debatte’, ASB 01.1000.

71 Andreas Blechschmidt is quoted in full as: 'Die Militanz Diskussion begleitet autonome Politik seit 40 Jahren. Es ist klar, dass nicht jede militante Aktion in Ordnung ist' in G20-Gipfel: Blockieren, lahmlegen, verzögern', Zeit, 28 June 2017, http://www.zeit.de/2017/27/g20-gipfel-demonstrationhamburg-rote-flora-widerstand/komplettansicht (accessed 1 April 2018)

72 See Ali Jones, 'Anti Anti Anti': Counterviolence and Anti-Sexism in Hamburg's Rote Flora, Sarah Colvin, ed, The Limits of Emancipation: Thinking Violence and Gender Post 1968, Routledge 2018, pp. 142-157.

73 Alfred, Interview with Author, 17 September 2016, Hamburg.

74 Pia, Interview with Author, 8 September 2017, Hamburg. 
75 See Anarchist_innen für die soziale Revolte, 'G20 - Tage der Revolt', in Autonome Gruppen, eds. Rauchzeichnen Worte und Taten gegen die Welt der G20, Self-Published Brochure, p. 12, ASB 0.000. (Hereafter Rauchzeichnen)

76 Block G20, ‘\#BlockG20 - Colour the Red Zone', http://www.blockg20.org/aktionsbild/ (accessed 1 April 2018).

77 CrimethInc, 'Don't try to break us, we'll explode: the 2017 G20 and the Battle of Hamburg: a Full Account and Analysis', Self-Published Brochure, 2017, p. 35, ASB 0.000. (This brochure was compiled and published by participants of the radical Marxist 'CrimethInc' collective, many of whom were involved in the riot. The brochure contains many articles by different Autonomist and Anarchist groups from across Europe.)

78 Anonymous, 'Colorfull Mass gegen den G20 am 7. Juli', Demonstration Flyer, ASB 14.000.

79 CrimethInc, p. 37.

80 Der Rote Aufbau, 'Mit uns gibt es Molotowcocktails statt Sektempfang' as cited in 'Der Rote Aufbau - kommunistisch orientiert', Hamburg Abendblatt, 6 December 2017, https://www.abendblatt.de/hamburg/article212751177/Der-Rote-Aufbau-kommunistisch-orientiert.html (accessed 1 April 2018).

81 CrimethInc, p. 35.

$82 \quad$ CrimethInc, p. 38.

$83 \quad$ Ibid.

84 Der Tageszeitung, 'Taz-Liveblog zum G20-Freitag, Schwere Krawalle im Schanzenviertel’, 7 July, 2017 http://www.taz.de/!5425982/ (accessed 1 April 2018).

85 Taz-Liveblog.

86 Alvaro Piña, 'Es war kein vorbereiteter Hinterhalt', $n d r . d e, 20$ July 2017, https://daserste.ndr.de/panorama/Es-war-kein-vorbereiteter-Hinterhalt,panorama7904.html (accessed 1 April 2018). 
87

Nicolai Kwasniewski, Dominik Peters und Ansgar Siemens, 'Gewalt beim G20-Gipfel "Wie im Krieg"' Spiegel Online, 7 July 2017, http:/www.spiegel.de/politik/deutschland/gewalt-beim-g20-gipfelwie-im-krieg-a-1156592.html (accessed 1 April 2018).

88 CrimethInc, p. 39; Taz-Liveblog.

89 Piña, 2017.

$90 \quad$ CrimethInc, p. 39. Original in English.

91 CrimethInc, p. 38. Original in English.

92 Taz-Liveblog.

$93 \quad$ Ibid.

$94 \quad$ Ibid.

95 Piña, 2017.

96 Malene Gürgen, 'Anwohner über G20-Krawalle "Mit den Kids ging die Randale los"', taz, 14 July 2017, https://www.taz.de/Anwohner-ueber-G20-Krawalle/!5426652/ (accessed 1 April 2018). $97 \quad$ Piña, 2017.

98 See Andreas Blechschmidt, (2009) 'Linke Parelleluniversen’ Jungle World, (17), 23 April 2009, http://jungle-world.com/artikel/2009/17/34155.html (accessed 1 February 2015); Maximilian Probst, 'Jetzt noch autonomer', ZEIT Online, (03), 9 January 2014, (https://www.zeit.de/2014/03/rote-florahamburg-autonome-gefahrengebiet/komplettansicht) accessed 30 May 2018; Laura Naegler, Gentrification and Resistance: Cultural Criminology, control, and the commodification of urban protest in Hamburg, Berlin 2012.

99 Mehmet, Interview with Author, 23 November 2016, Hamburg.

100 Katja, Interview with Author, 2 March 2018, Hamburg.

101 Katja, Interview with Author, 2 March 2018, Hamburg.

102 Piña, 2017.

103 Pia, Interview with Author, 08 September 2017, Hamburg. Original in English.

104 Sophia, Interview with Author, 4 March 2018, Hamburg. 
Pia, Interview with Author, 08 September 2017, Hamburg. Original in English; Holger Dambeck, Eva Horn, Philipp Löwe, Dominik Peters, Stefan Schultz and Ansgar Siemens, 'G20 Protests: Police Opt for Brute Force in Hamburg', Der Spiegel Online, 7 July 2017, http://www.spiegel.de/international/germany/hamburg-g20-protests-met-with-excessive-force-by-policea-1156549.html, (accessed 29 May 2018).

106 autonomous \& anticapitalist alliance against the G20-summit in Hamburg, 'Welcome to hell! Call to action', https://g20tohell.blackblogs.org/g20-welcome-to-hell/ (accessed 29 May, 2018).

107 Piña, 2017.

$108 \quad$ Ibid.

109 'Amateurvideo aus Hamburg: Schwarzer Block verwüstet Wohnstraße', Der Spiegel Online, 7 July 2017, http://www.spiegel.de/video/krawalle-beim-g20-gipfel-brandstiftungen-in-hamburg-video1780781.html (accessed 1 April 2018).

110 Pia, Interview with Author, 8 September 2017, Hamburg.

$111 \quad$ Ibid.

112 Andreas Blechschmidt, Interview, $n d r . d e$, posted to twitter, 7 July 2017, https://twitter.com/ndr/status/883557335393849344, (accessed 1 April 2018).

113 Peter Mühlfeit, 'Strobl fordert Datei für Linksextremisten’, swr.de, 10 July 2017, https://www.swr.de/swraktuell/reaktionen-auf-g20-krawalle-strobl-fordert-datei-fuer-linksextremisten//id=396/did=19868868/nid=396/z7o1j5/index.html (accessed 1 April 2018).

114 Thomas de Maizière, cited in 'Nach G20-Krawallen De Maizière knöpft sich gewaltbereite Linke vor' [sic], heute.de, 10 July 2017, http://www.heute.de/nach-g20-krawallen-in-hamburg-innenministerde-maiziere-knoepft-sich-gewaltbereite-linke-vor-47547410.html (accessed 1 April 2018); Mike Schlink, 'Offener Brief der G20-Aktivisten “Sind keine Krawallmacher”, Hamburg Morgenpost, 19 May 17, http://www.mopo.de/26927942 (accessed 1 April 2018).

115 Note that different sources cite different numbers, ranging from 132-158 Germans, 20-37 Italians, and 17-25 French. 'Mehr als 400 Festnahmen Wer sind die G20-Randalierer?', 25 July 2017, 


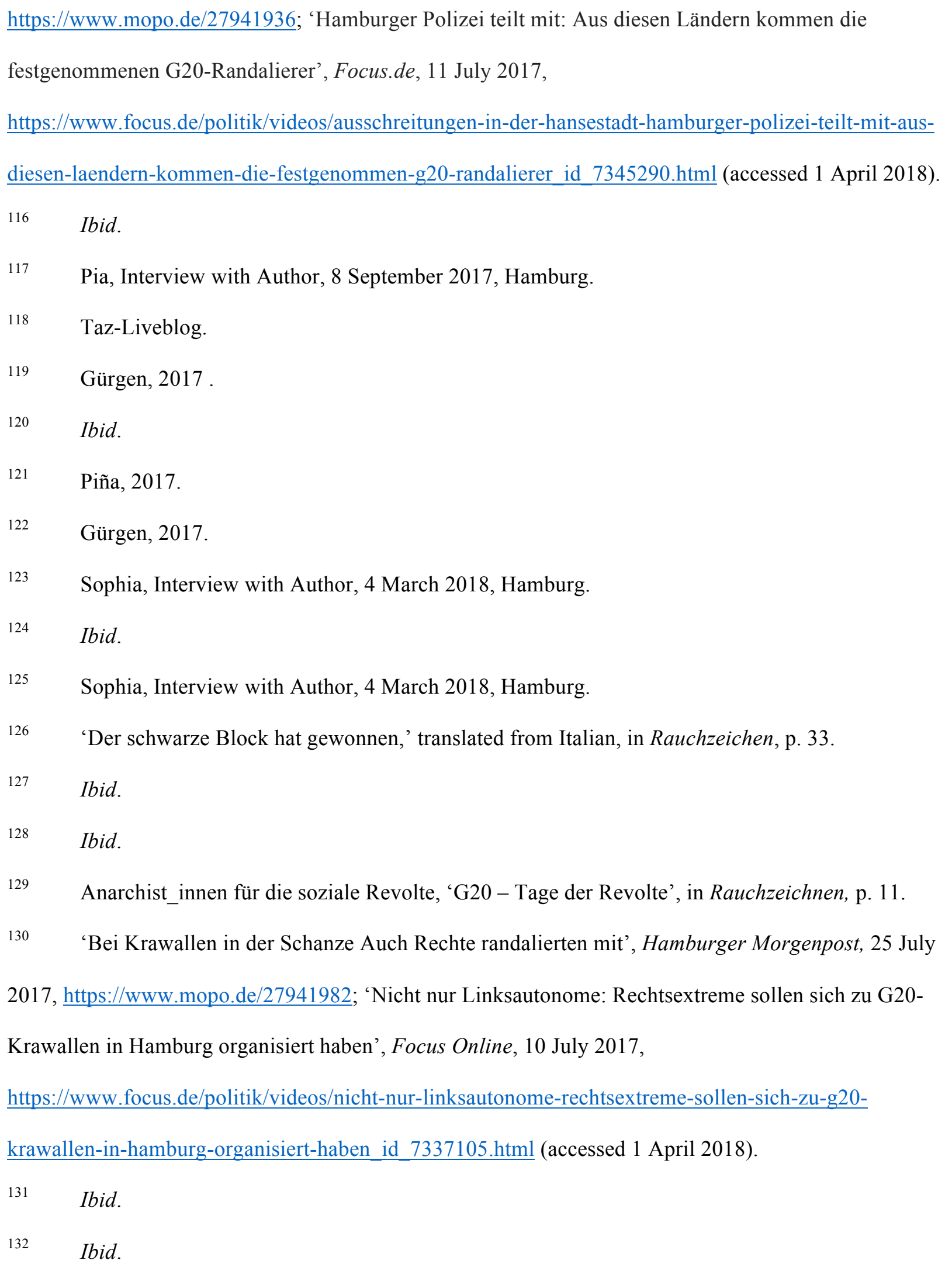


Britta Kollenbroich, Dominik Peters, 'Schuss in der Schanze', Der Spiegel Online, 8 July 2017, http://www.spiegel.de/panorama/justiz/g20-einsatz-in-hamburg-warum-ein-polizist-in-der-schanze-

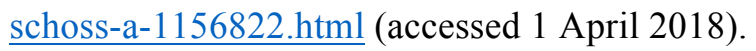

$134 \quad$ Ibid.

135 Ibid.

136 'Der schwarze Block hat gewonnen,' translated from Italian, in Rauchzeichen, p. 34.

137 Blechschmidt, Interview, ndr.de.

138 Pia, Interview with Author, 08 September 2017, Hamburg .

139 Philipp Schmidt, Interview with Andreas Blechschmidt, 'Eskalation als Polizeikonzept', konkret, 29 August 2017.

$140 \quad$ 'Welcome to Hell Einladung', ASB 01.001.

$141 \quad$ Blechschmidt, Interview, ndr.de.

142 Linus, Interview with Author, 20 August 2016, Hamburg.

143 https://www.g20hamburg.org/ku/content/stadtplane (accessed 1 April 2018).

144 'G-20-Gegner markieren Reichenviertel als Protestziele', Welt, 19 May 2017, ASB 14.000.

145 Anarchist_innen für die soziale Revolte, in Rauchzeichnen, p. 20. Emphasis mine.

$146 \quad$ Ibid.

$147 \quad$ Ibid.

$148 \quad$ Ibid.

149 Andreas Beuth, NDR aktuell, 8 July 2017, cited in Andreas Beuth, 'Versuch einer Selbstkritik oder der Ritt durch die Hölle', Zeck, No. 200, December 2017, p. 8.

150 Andreas Beuth, 'Versuch einer Selbstkritik oder der Ritt durch die Hölle', Zeck, No. 200, December 2017, p. 8.

151 Der Tagezeitung, 'Flora-Anwalt Andreas Beuth über die G-20-Ausschreitungen: Ein Imageschaden ohnegleichen', 11 July 2017, http://www.taz.de/!5425733/ (accessed 5 April 2018). 
152 Autonome aus Irgendwo, 'Freude schöner Götterfunken,' in Rauchzeichen, p. 21.

153 Piña, 2017.

154 Pia, Interview with Author, 08 September 2017, Hamburg.

155 Ibid.

156 Die unsichbaren Freunde, 'Die öffentliche Verschwörung: Der Aufruh in Hamburg', in

Rauchzeichen, p. 8.

$157 \quad$ Ibid.

158 See Alexander Vasudevan, Metropolitan Preoccupations: The Spatial Politics of Squatting, Malden, MA 2015.

159 Die unsichbaren Freunde, 'Die öffentliche Verschwörung: Der Aufruh in Hamburg', in Rauchzeichen, p. 8.

$160 \quad$ Blechschmidt, Interview, $n d r . d e$.

161 Andreas Blechschmidt,' G20-Gipfel: Blockieren, lahmlegen, verzögern', Zeit, 28 June 2017, http://www.zeit.de/2017/27/g20-gipfel-demonstration-hamburg-rote-flora-widerstand/komplettansicht (accessed 1 April 2018). 